Article

\title{
Scalable Green Approach Toward Fragrant Acetates
}

\author{
Eva Puchl'ová and Peter Szolcsányi * (1) \\ Department of Organic Chemistry, Slovak University of Technology, Radlinského 9, 81237 Bratislava, Slovakia; \\ eva.puchlova@stuba.sk \\ * Correspondence: peter.szolcsanyi@stuba.sk
}

Received: 18 June 2020; Accepted: 13 July 2020; Published: 14 July 2020

check for

updates

\begin{abstract}
The advantageous properties of ethylene glycol diacetate (EGDA) qualify it as a useful substitute for glycerol triacetate (GTA) for various green applications. We scrutinised the lipase-mediated acetylation of structurally diverse alcohols in neat EGDA furnishing the range of naturally occurring fragrant acetates. We found that such enzymatic system exhibits high reactivity and selectivity towards activated (homo) allylic and non-activated primary/secondary alcohols. This feature was utilised in the scalable multigram synthesis of fragrant (Z)-hex-3-en-1-yl acetate in $70 \%$ yield. In addition, the Lipozyme 435/EGDA system was also found to be applicable for the chemo-selective acetylation of (hydroxyalkyl) phenols as well as for the kinetic resolution of chiral secondary alcohols. Lastly, its discrimination power was demonstrated in competitive experiments of equimolar mixtures of two isomeric alcohols. This enabled the practical synthesis of 1-pentyl acetate isolated as a single product in $68 \%$ yield from the equimolar mixture of 1-pentanol and 3-pentanol.
\end{abstract}

Keywords: enzymatic acetylation; green solvents; chemo-selectivity

\section{Introduction}

In perfumery and the flavour industry, acetates are the most important aliphatic esters used and valued for their typical aromas [1]. Although most of them are natural products, their isolation from sources of origin makes the process economically unfeasible. Therefore, numerous chemical approaches toward fragrant acetates were successfully developed using homogenous or heterogeneous acid, base, or transition-metal catalysis [2]. However, perfumery and flavour grade esters need to be free of inorganic impurities and undesirable colouration. Moreover, increasing the health consciousness and environmental issues strongly encourages the development of benign yet efficient biocatalytic protocols as viable green alternatives [3]. Among them, the use of lipases gained considerable attention due to their high reactivity and remarkable selectivity under diverse reaction conditions [4]. In addition, their stability in a non-aqueous environment, particularly under solvent-free conditions, gives lipases a comparative advantage over other biocatalysts [5]. In this context, glycerol-based solvents [6-8] and/or reagents represent a green alternative to commonly used reaction media. One of the perspective glycerol's derivatives is triacetin (glycerol triacetate, GTA), which was recently used both as a reagent and solvent for the enzymatic acetylation of some alcohols [9-12]. A similar and commercially available derivative, ethylene glycol diacetate (EGDA) can be considered an interesting alternative to GTA for analogous transformations. With the lower boiling point and viscosity, better recyclability, and regeneration, EGDA has a promising synthetic potential for the scalable preparation of natural acetates for perfumery and/or flavour purposes.

Therefore, we have decided to scrutinise the practical use of EGDA for the enzymatic acetylation of selected alcohols that would afford known and naturally occurring fragrant acetates. In addition, we were interested in the chemo-selectivity of such a reaction system with respect to the structure and/or reactivity of substrates of commercial interest. 


\section{Results and Discussion}

The initial reaction screening was done on (Z)-hex-3-ene-1-ol 1 as a model substrate, which was acetylated [13-15] either in neat EGDA or with the cosolvent (MTBE or hexane) using Lipozyme 435 as a biocatalyst to afford (Z)-hex-3-ene-1-yl acetate 2 . The enzyme and EGDA loadings as well as temperature, concentration, and co-solvent were scrutinised as variable parameters while the progress of the reaction was monitored by GC-FID (see Table S1 in the Supporting Information). The identified optimal reaction conditions were then applied for the scale-up preparation of fragrant acetate 2 in $70 \%$ yield. It is noteworthy that the isolation and purification protocol involves environmentally benign procedures only (filtration, hydrodistillation, and vacuum rectification) and is free of chromatography and/or any additional organic solvents (Scheme 1).

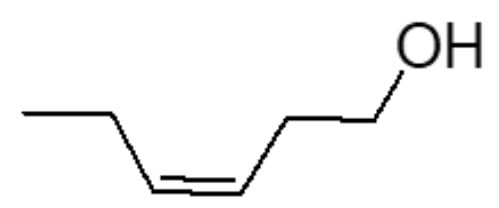

1
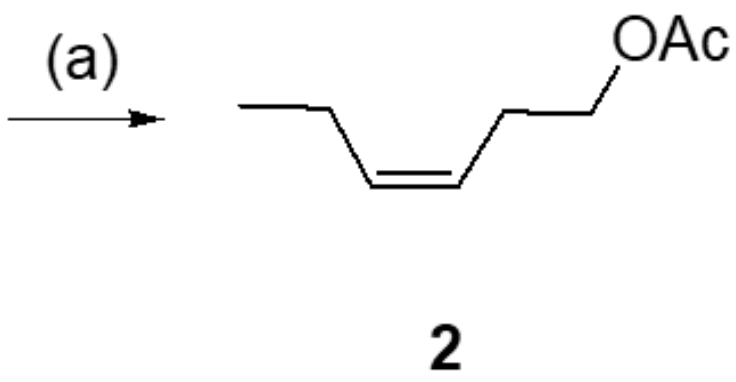

Scheme 1. Optimised preparation of fragrant (Z)-hex-3-ene-1-ol 1. Reagents and conditions: (a) Ethylene glycol diacetate (EGDA) (2 equiv), Lipozyme 435 ( $2 \% \mathrm{wt}), 40{ }^{\circ} \mathrm{C}, 150 \mathrm{rpm}, 70 \%$ yield ( $20 \mathrm{~g}$ scale).

Next, we have applied the optimal reaction conditions in the acetylation screening of various alcohols (Scheme 2) that furnish naturally occurring fragrant acetates (entries 1-14, Table 1). In parallel, we have investigated the chemo-selectivity of such an enzymatic system for discrimination between structurally different alcohols by adding more substrates (entries 15-20, Table 1) —regardless of aroma properties of their acetates-to the screening for comparison purposes. The obtained results clearly show the following reactivity patterns.

(a) Considering the activated substrates, allylic primary alcohols 3, 5, 7, 9, 13, and 15 (entries $2-5,7,8)$ were almost quantitatively esterified (GC-FID ratios of alcohol to acetate ranging from 10:90 to 4:96) to fragrant acetates, namely geranyl acetate 4 [16-34], prenyl acetate 6, (E)-2-hexenyl acetate 8, cinnamyl acetate 10 [35-41], phytyl acetate $(E / Z=66: 34) 14$ [42], and $(1 R)$-nopyl acetate 16, respectively. On the other hand, rac-linalool 11 remained almost intact with negligible acetylation only (entry 6). Furthermore, the enzyme clearly discriminates between the primary and tertiary allylic alcohol. Analogously, the primary homoallylic alcohols $\mathbf{1}$ and $\mathbf{1 7}$ also provided corresponding fragrant acetates (entries 1 and 9), namely (Z)-hex-3-ene-1-yl acetate 2 and (1R)-myrtenyl acetate 18.

(b) Regarding the non-activated substrates, the enzyme clearly distinguishes primary alcohols 27, 29 (entries 15, 16), and/or secondary alcohols 19, 21, 23, 33, and 35 (entries 10-13, 18, 19) vs. phenolic eugenol 31 (entry 17) and/or tertiary alcohol 37 (entry 20). While the former ones were reasonably acetylated (although not as well as activated alcohols, vide supra) to their corresponding acetates $\mathbf{2 0}, \mathbf{2 2}, \mathbf{2 4}, \mathbf{2 8}, \mathbf{3 0}, \mathbf{3 4}$, and $\mathbf{3 6}$, the latter ones were fully reluctant to the transformation. In addition, the enzyme's enantio-discrimination led to the kinetic resolution of racemic secondary alcohols 19, 21 (entries 10, 12). In the case of rac-2-heptanol 19 (entry 10), (R)-enantiomer was mostly acetylated [43-49] as shown by negligible formation of (S)-2-heptenyl acetate $(S)$-20 (see Figure S1 in the Supporting Information), and, thus, by obeying the Kazlauskas's rule [50] (entry 11). Conversely, (1R)-endo-fenchol 25 remained practically intact. This might be due to the significant steric congestion around the hydroxyl group and/or the result of the enantiomer preference of the enzyme for the opposite enantiomer (entry 14). In addition, the enzymatic acetylation [51-53] 
of bifunctional rac-rhododendrol 21 exhibited both the chemo-selectivity (alcohol vs. phenol) and the kinetic resolution of racemate (entry 12). Thus, the secondary hydroxyl group of the $(R)$-enantiomer (cf. the Kazlauskas's rule again) was mostly acetylated to furnish the ester $(R)-22$ along with the enantiomerically enriched $(S)$-rhododendrol $(S)-21$ (84\% ee, chiral HPLC, see Figure S2 in the Supporting Information). The clear unreactivity of phenols under the reaction conditions was also exhibited by zero acetylation of eugenol 31 (entry 17).

(c) Considering the achiral secondary alcohols, even minor structural differences led to a significant change in their reactivity. While isopropanol 35 (entry 19) was acetylated in a major extent (GC-FID ratio 35/36 = 15:85), slightly larger pentan-3-ol 33 (entry 18) was much less reactive (GC-FID ratio 33/34 = 45:55). The extent of acetylation of 2-indanol 23 (entry 13), being somewhere in between (GC-FID ratio $\mathbf{2 3} / \mathbf{2 4}=\mathbf{2 4 : 7 6 )}$, might indicate the high sensitivity of the respective lipase to the steric demands of the alcohols in question.

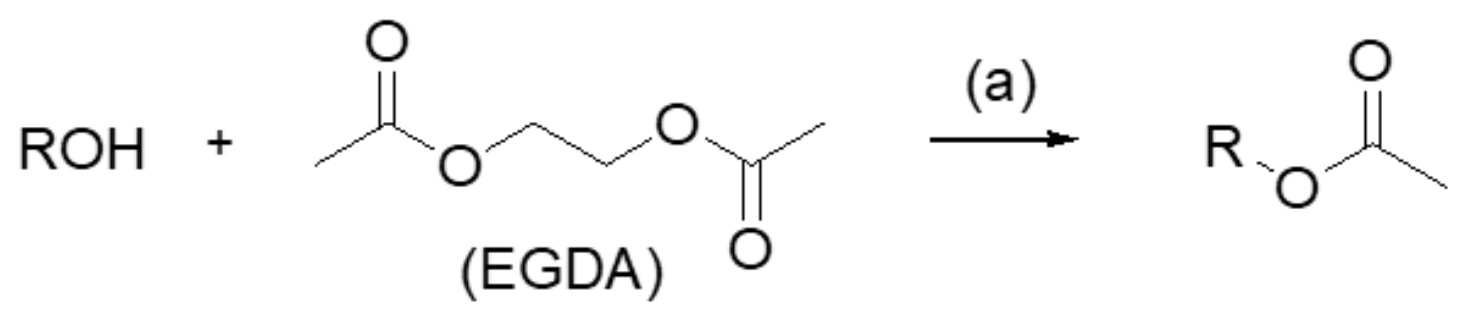

Scheme 2. Reaction screening of the enzymatic acetylation. Reagents and conditions: (a) EGDA (2 equiv), Lipozyme 435 ( $2 \% \mathrm{wt}), 40{ }^{\circ} \mathrm{C}, 150 \mathrm{rpm}$, Table 1.

Next, we aimed to practically utilise the observed chemo-selectivity of the enzymatic system, and, therefore, we tested its discrimination power on two-component mixtures of similar yet different alcohols. Thus, we have performed competitive acetylation experiments with equimolar mixtures of four pairs of alcohols: (a) 1-pentanol 39 vs. 3-pentanol 33, (b) 3-pentanol 33 vs. cyclopentanol 41, (c) prenol 5 vs. divinylcarbinol 43, and (d) 3-pentanol 33 vs. divinylcarbinol 43 (Scheme 3 and Table 2). The obtained results clearly show that lipase-catalysed acetylation provided excellent discrimination between primary and secondary alcohols in favour of the former ones (Table 2, entries 1 and 3 ). Thus, primary 1-pentanol 39 was almost exclusively acetylated to 1-pentyl acetate 40 (GC-FID ratio $39 / 40=6: 94)$ at the expense of its secondary isomer 3-pentanol 33 that barely afforded its acetate 34 (GC-FID ratio 33/34 = 96.5:3.5). Similarly, primary allylic prenol 5 was overwhelmingly acetylated to prenyl acetate 6 (GC-FID ratio 5/6 =9:91) in the presence of secondary divinylcarbinol 43 that was concomitantly transformed to its acetate 44 in a minor extent only (GC-FID ratio 43/44=81:19). On the other hand, the chemo-selectivity of competitive enzymatic acetylation of cyclic vs. acyclic secondary alcohols was less pronounced (Table 2, entry 2). Although cyclopentanol 41 was acetylated much faster to its acetate 42 (GC-FID ratio 41/42 = 19:81) than acyclic 3-pentanol 33 to 3-pentyl acetate 34 (GC-FID ratio $33 / 34=80: 20$ ) due to the necessary longer reaction time, the discrimination factor was inevitably reduced. On the other hand, the preferential acetylation of $\mathbf{4 1}$ over $\mathbf{3 3}$ might be attributed to the higher reactivity of less sterically hindered and more nucleophilic hydroxyl group of cyclopentanol $\mathbf{4 1}$ when compared to conformationally more flexible 3-pentanol 33. Lastly, the reactivity of non-activated (alkylic) vs. activated (allylic) secondary alcohols was comparable. This was evident from the competitive acetylation of an equimolar mixture of 3-pentanol 33 and divinylcarbinol 43, which generated their corresponding acetates 34 and 44 without significant discrimination between each other (Table 2, entry 4). The time-dependent evolution of the ratio between forming acetates is depicted in Figure 1. For the corresponding analytical data, see Tables S3-S6 in the Supporting Information. 
Table 1. Screening of the enzymatic acetylation of alcohols according to Scheme 2.

\begin{tabular}{|c|c|c|c|c|}
\hline Entry & Alcohol & Acetate & Time (h) & GC-FID Ratio ${ }^{a}(\%)$ \\
\hline 1 & & & 19 & $6: 94$ \\
\hline 2 & & & 24 & 5:95 \\
\hline 3 & & & 23 & $4: 96$ \\
\hline 4 & & & 24 & $5: 95$ \\
\hline 5 & & & 48 & 8:92 \\
\hline 6 & & & 72 & $91: 9$ \\
\hline 7 & & & 24 & $4: 96$ \\
\hline 8 & & & 24 & 10:90 \\
\hline 9 & & & 24 & $6: 94$ \\
\hline 10 & & & 20 & $48: 52$ \\
\hline 11 & & & 72 & $91: 9$ \\
\hline 12 & & & 48 & $52: 48$ \\
\hline 13 & & & 72 & $24: 76$ \\
\hline 14 & & & 48 & $98: 2$ \\
\hline 15 & & & 72 & 14:86 \\
\hline 16 & & & 42 & $11: 89$ \\
\hline 17 & & & 48 & $100: 0$ \\
\hline 18 & & & 51 & $45: 55$ \\
\hline 19 & & & 48 & $15: 85$ \\
\hline 20 & & & 48 & 100:0 \\
\hline
\end{tabular}

${ }^{a}$ The compositions were obtained by GC-FID analysis by comparing peak areas of alcohol vs. acetate. 


\section{$\mathrm{R}^{1} \mathrm{OH}+\mathrm{R}^{2} \mathrm{OH} \stackrel{(\mathrm{a})}{\longrightarrow} \mathrm{R}^{1} \mathrm{OAc}+\mathrm{R}^{2} \mathrm{OAc}$}

Scheme 3. Chemo-selective acetylation of equimolar mixtures. Reagents and conditions: (a) alcohols (1:1), ethylene glycol diacetate (EGDA) (1 equiv), Lipozyme 435 ( $1 \% \mathrm{wt}), 40{ }^{\circ} \mathrm{C}, 150 \mathrm{rpm}$, Table 2.

Table 2. Screening of competitive enzymatic acetylation of equimolar mixtures of alcohols according to Scheme 3.

\begin{tabular}{|c|c|c|c|c|c|}
\hline Entry & Substrates $\mathrm{R}^{1} \mathrm{OH}+\mathrm{R}^{2} \mathrm{OH}$ & Products $R^{1} \mathrm{OAc}+\mathrm{R}^{2} \mathrm{OAc}$ & Time (h) & $\begin{array}{c}\mathrm{R}^{1} \mathrm{OH} / \mathrm{R}^{1} \mathrm{OAc} \\
(\text { GC-FID Ratio \%) }\end{array}$ & $\begin{array}{c}\mathrm{R}^{2} \mathrm{OH} / \mathrm{R}^{2} \mathrm{OAc} \\
\text { (GC-FID Ratio \%) }\end{array}$ \\
\hline 1 & & & 8 & $39 / 40(6: 94)$ & $33 / 34(96.5: 3.5)$ \\
\hline 2 & (41) & (42) & 48 & 41/42 (19:81) & $33 / 34(80: 20)$ \\
\hline 3 & H & $\mathrm{OAC}+$ & 24 & $5 / 6(9: 91)$ & $43 / 44(81: 19)$ \\
\hline 4 & $+\nabla$ & $+>$ & 56 & $33 / 34(66: 34)$ & 43/44 (51:49) \\
\hline
\end{tabular}

a The compositions were obtained by GC-FID analysis by comparing peak areas of respective alcohol vs. its acetate.
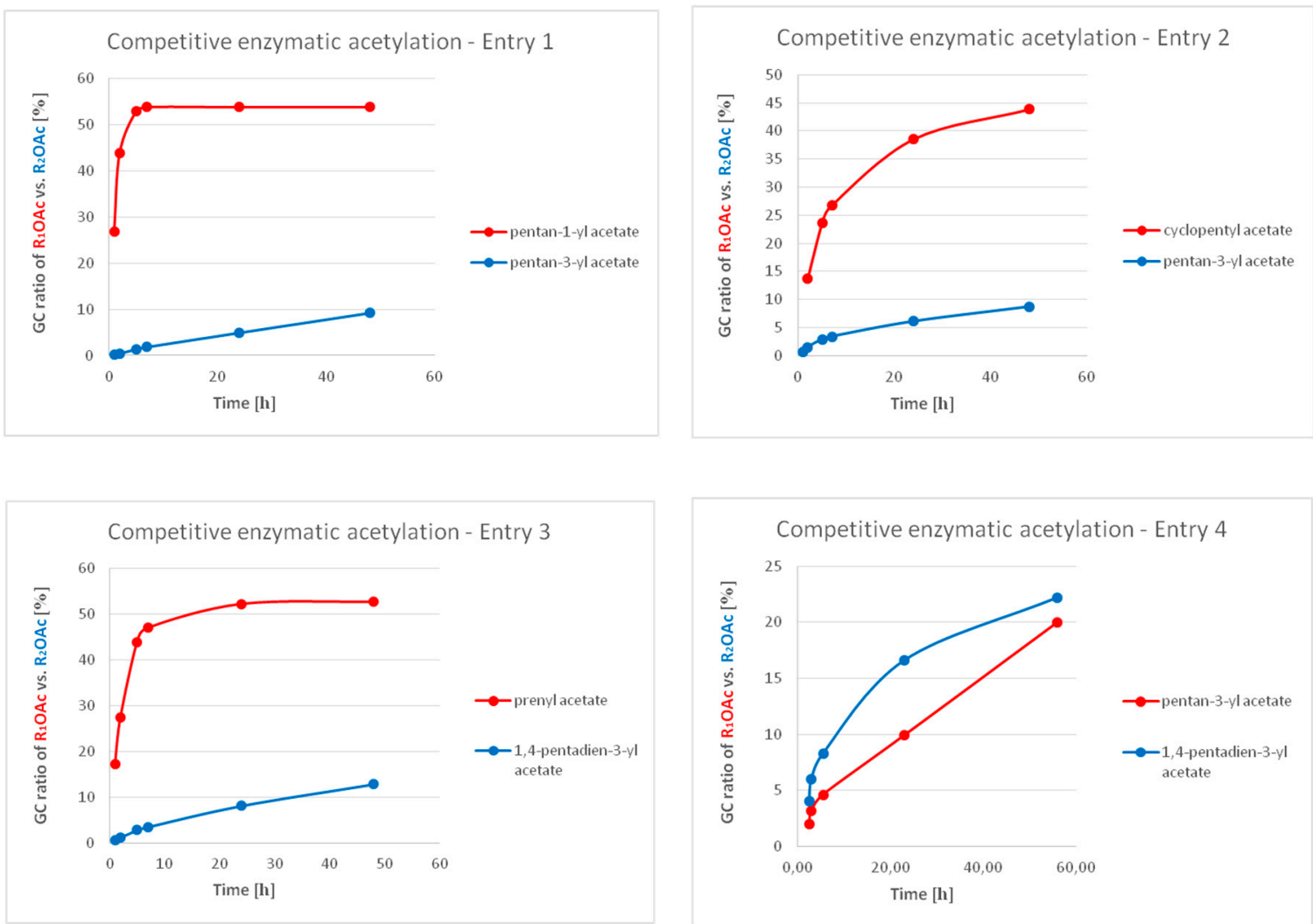

Figure 1. Time-dependent evolution of the ratio between forming acetates during competitive experiments (cf. Scheme 3, cf. Tables S3-S6 in the Supporting Information).

The observed enzymatic discrimination between interrelated alcohols could be potentially used for the chemo-selective acetylation of their mixtures and/or for the reactive separation of product-of-choice from a multi-component (raw) material. To verify such an approach on a model system, the 
preparative-scale enzymatic acetylation of an equimolar mixture (5 g each) of 1-pentanol 39 and 3-pentanol 33 was carried out. In order to maximise the chemo-selectivity, we have lowered the amount of both the enzyme and EGDA loading by half in comparison to standard conditions (cf. Scheme 2). Thus, after gentle heating and stirring the reaction mixture for less than $5 \mathrm{~h}$, which was followed by its hydrodistillation and final extraction of distillate, 1-pentyl acetate 40 was isolated in $68 \%$ yield (Scheme 4).

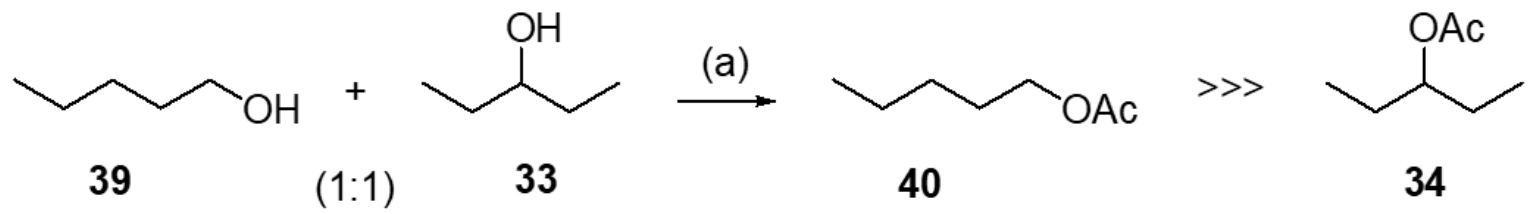

Scheme 4. Chemo-selective acetylation of equimolar mixture of alcohols. Reagents and conditions: (a) $39+33$ (1:1), EGDA (1 equiv), Lipozyme 435 (1\% wt), $40{ }^{\circ} \mathrm{C}, 150 \mathrm{rpm}, 4.5$ h, 40 (94\% GC-FID purity, $68 \%$ yield from 39$)$.

\section{Materials and Methods}

\subsection{Materials and Methods}

Chemicals and reagents were purchased from commercial sources (Alfa Aesar, Sigma-Aldrich, Merck) and were used without further purification. Hexanes refer to a mixture of C-6 alkanes (b.p. 60-80 ${ }^{\circ} \mathrm{C}$ ). Lipozyme 435 (Candida antarctica lipase B immobilized on a macroporous acrylic resin) with a reported activity of 8000 PLU (propyl laurate units) per gram was purchased from Novozymes A/S (Bagsværd, Denmark). All GC-FID analyses were performed on a gas chromatograph Agilent 7890A equipped with FID and a split-splitless injector as follows: (a) standard GC-FID using column DB-WAX $(30 \mathrm{~m} \times 0.25 \mathrm{~mm} \times 0.15 \mu \mathrm{m})$, for rhododendrol 21: injection $1.0 \mu \mathrm{L}$, split 20:1, temperature gradient $60{ }^{\circ} \mathrm{C}(0 \mathrm{~min}) \rightarrow 20{ }^{\circ} \mathrm{C} / \mathrm{min} \rightarrow 200{ }^{\circ} \mathrm{C}(25 \mathrm{~min})$, carrier gas $\mathrm{H}_{2}$, flow $1.2 \mathrm{~mL} / \mathrm{min}$, for all the rest of alcohols (except phytol 13): injection $0.01 \mu \mathrm{L}$, split 50:1, temperature gradient $40{ }^{\circ} \mathrm{C}(0 \mathrm{~min})$ $\rightarrow 10^{\circ} \mathrm{C} / \mathrm{min} \rightarrow 200{ }^{\circ} \mathrm{C}$ (12 $\left.\mathrm{min}\right)$, carrier gas $\mathrm{H}_{2}$, flow $1.2 \mathrm{~mL} / \mathrm{min}$, (b) standard GC-FID for phytol 13 using column DB-5 $(30 \mathrm{~m} \times 0.25 \mathrm{~mm} \times 0.25 \mu \mathrm{m})$, injection $0.01 \mu \mathrm{L}$, split 50:1, temperature gradient $40{ }^{\circ} \mathrm{C}(0 \mathrm{~min}) \rightarrow 10{ }^{\circ} \mathrm{C} / \mathrm{min} \rightarrow 200{ }^{\circ} \mathrm{C}(12 \mathrm{~min})$, carrier gas $\mathrm{H}_{2}$, flow $1.2 \mathrm{~mL} / \mathrm{min}$, (c) chiral GC-FID using column Lipodex-A $(50 \mathrm{~m} \times 0.25 \mathrm{~mm} \times 0.25 \mu \mathrm{m})$, injection $0.2 \mu \mathrm{L}$, split $50: 1,55^{\circ} \mathrm{C}(50 \mathrm{~min})$ isothermal, carrier gas $\mathrm{H}_{2}$, flow $2.0 \mathrm{~mL} / \mathrm{min}$ ). All GC-MS analyses (except rhododendrol 21) were performed on a gas chromatograph Agilent 7890A coupled with Agilent 5975C inert MSD with Triple-Axis Detector (column DB-Wax $30 \mathrm{~m} \times 0.25 \mathrm{~mm} \times 0.15 \mu \mathrm{m}$, injection $0.1 \mu \mathrm{L}$, split 20:1, temperature gradient $40^{\circ} \mathrm{C}$ $(0 \mathrm{~min}) \rightarrow 10{ }^{\circ} \mathrm{C} / \mathrm{min} \rightarrow 200{ }^{\circ} \mathrm{C}(12 \mathrm{~min})$, carrier gas $\mathrm{H}_{2}$, flow $\left.1.0 \mathrm{~mL} / \mathrm{min}\right)$, for rhododendrol 21: temperature gradient $60{ }^{\circ} \mathrm{C}(0 \mathrm{~min}) \rightarrow 20^{\circ} \mathrm{C} / \mathrm{min} \rightarrow 220^{\circ} \mathrm{C}(25 \mathrm{~min})$, carrier gas $\mathrm{H}_{2}$, flow $\left.1.0 \mathrm{~mL} / \mathrm{min}\right)$. To monitor the reaction progress, the relative amount (reported as a percentage) of each component (alcohol vs. acetate) was determined according to the proportion of each peak area in the total peak area of the two compositions. The chemical identity of prepared acetates was determined as follows: (a) GC-FID comparison with the commercial standard for 2, 4, 6, 8, rac-20, (S)-20, (b) GC-MS (NIST library) for 10, 12, 14, 16, 18, rac-20, (S)-20, rac-22, 24, 26, 28, 34, 36, (c) ${ }^{1} \mathrm{H}$ NMR for rac-22, 30. NMR spectra were recorded on a Varian INOVA 300 spectrometer and were correctly shifted using residual non-deuterated solvent $\left(\mathrm{CHCl}_{3}: \delta_{\mathrm{H}}=7.26 \mathrm{ppm}\right)$. Chiral HPLC analyses were performed on Agilent 1260 Infinity LC system equipped with a Lux ${ }^{\circledR}$ Amylose- 1 column $(250 \times 4.6 \mathrm{~mm}, 5 \mu \mathrm{m}$, stationary phase: amylose tris-(3,5-dimethylphenyl) carbamate, Phenomenex, Torrance, CA, USA) and diode-array detector $(220 \mathrm{~nm})$. The separation was carried out at $15^{\circ} \mathrm{C}$ by isocratic elution with $n$-hexane/isopropanol $(90: 10, v / v)$ with the flow rate of $1 \mathrm{~mL} / \mathrm{min}$.

\subsection{Synthetic Procedures and Analytical Data}

General experiment for the optimisation screening of acetylation of (Z)-hex-3-en-1-ol (1): 
To a solution of an alcohol $(10.0 \mathrm{mmol})$ in either neat EGDA or EGDA/cosolvent mixture was added Lipozyme 435. The reaction mixture was stirred in an orbital shaker (150 rpm) at two different temperatures ( 40 or $45^{\circ} \mathrm{C}$, respectively) and the reaction progress was monitored by GC-FID (see Table S1 in the Supporting Information).

General experiment for the optimised acetylation of alcohols, according to Scheme 2:

Lipozyme 435 ( $2 \% \mathrm{wt}$ ) was added to a solution of an alcohol (1 equiv) in EGDA (2 equiv). The reaction mixture was incubated in an orbital shaker $\left(40^{\circ} \mathrm{C}, 150 \mathrm{rpm}\right)$ and the reaction progress was monitored by GC-FID (see Table 1).

Scale-up preparation of (Z)-hex-3-en-1-yl acetate (2):

Lipozyme 435 (400 mg, 2\% wt) was added to a solution of (Z)-hex-3-en-1-ol 1 (20.0 g, $0.2 \mathrm{~mol})$ in EGDA $(58.3 \mathrm{~g}, 0.4 \mathrm{~mol})$. The reaction mixture was incubated in an orbital shaker $\left(40{ }^{\circ} \mathrm{C}, 150 \mathrm{rpm}\right)$ and the reaction progress was monitored by GC-FID. The enzyme was filtered off and the filtrate was hydro-distilled. The separated organic phase was purified by vacuum rectification (b.p. $62-63{ }^{\circ} \mathrm{C} / 20$ mbar) affording (Z)-hex-3-en-1-yl acetate 2 in two fractions as colourless oils: first fraction $(8.11 \mathrm{~g}, 80 \%$ GC-FID purity, containing $6.48 \mathrm{~g}$ of 2 ) and second fraction (13.35 g, 95.7\% GC-FID purity, containing $12.80 \mathrm{~g}$ of 2$)$ in a combined $70 \%$ yield. ${ }^{1} \mathrm{H} \mathrm{NMR}\left(300 \mathrm{MHz}, \mathrm{CDCl}_{3}\right): \delta=5.53-5.45(\mathrm{~m}, 1 \mathrm{H}, \mathrm{H}-3)$, $5.35-5.26(\mathrm{~m}, 1 \mathrm{H}, \mathrm{H}-4), 4.05(\mathrm{t}, J=6.9 \mathrm{~Hz}, 2 \mathrm{H}, \mathrm{H}-1), 2.39-2.32(\mathrm{~m}, 2 \mathrm{H}, \mathrm{H}-2), 2.09-2.00(\mathrm{~m}, 5 \mathrm{H}, \mathrm{H}-5$, $\mathrm{Me}), 0.96(\mathrm{t}, J=7.5 \mathrm{~Hz}, 3 \mathrm{H}, \mathrm{H}-6) .{ }^{13} \mathrm{C} \mathrm{NMR}\left(75 \mathrm{MHz}, \mathrm{CDCl}_{3}\right): \delta=171.3(\mathrm{C}=\mathrm{O}), 134.7(\mathrm{C}-4), 123.8$ (C-3), 64.1 (C-1), 26.8 (C-2), 21.1 (Me), 20.7 (C-5), 14.3 (C-6). The obtained data fully correspond to the reported spectra [54].

Enzymatic acetylation of rhododendrol (21) for the identification purposes:

Lipozyme 435 (10 mg, 2\% wt) was added to a suspension of racemic rhododendrol 21 (0.50 g, $30.1 \mathrm{mmol})$ in EGDA $(0.88 \mathrm{~g}, 60.2 \mathrm{mmol}, 2$ equiv). The reaction mixture was incubated in an orbital shaker $\left(40{ }^{\circ} \mathrm{C}, 150 \mathrm{rpm}\right)$ and GC-FID monitored the progress of the reaction. The enzyme was filtered off, the filtrate was diluted with $\mathrm{Et}_{2} \mathrm{O}(10 \mathrm{~mL})$, and it was washed with $2 \mathrm{M}$ aq. $\mathrm{NaOH}(15 \mathrm{~mL})$ to separate the unreacted enantiomer of the substrate [55]. The aqueous layer was washed with $\mathrm{Et}_{2} \mathrm{O}$ $(10 \mathrm{~mL})$ and acidified with $9 \%$ aq. $\mathrm{HCl}$ to $\mathrm{pH}$ 6. After extraction of the aqueous phase with $\mathrm{Et}_{2} \mathrm{O}$ $(10 \mathrm{~mL})$, the separated organic phase was dried over anhydrous $\mathrm{Na}_{2} \mathrm{SO}_{4}$, filtered, and evaporated in vacuo to furnish an oil. An aliquot sample of the crude material was subjected to proton NMR [56] and GC-MS [57] analyses to identify the acetate 22, and the obtained spectra fully corresponded to the reported data. In the alternative experiment, after completion of the reaction, the enzyme was filtered off, the filtrate was diluted with water, and it was extracted with methyl tert-butyl ether (MTBE). The separated organic phase was dried over $\mathrm{Na}_{2} \mathrm{SO}_{4}$ and concentrated in vacuo to furnish an oil. An aliquot sample of the crude material was purified by flash liquid chromatography (FLC) (silica gel, DCM/MeOH 95:5) to obtain two fractions: the first one containing the less polar acetate 22 $\left(R_{f}=0.60\right)$ and the second fraction containing the more polar alcohol $21\left(R_{f}=0.34\right)$. The latter one was then analyzed on chiral HPLC and was found to contain enantiomerically enriched (S)-rhododendrol (S)-21 (e.r. = 92/8, see Figure S2 in the Supporting Information, the enantiomeric elution order was adopted from Reference [58]).

Enzymatic acetylation of pent-3-yn-1-ol (29) for identification purposes:

Lipozyme 435 (20 mg, 2\% wt) was added to a solution of pent-3-yn-1-ol 29 (1.0 g, $11.9 \mathrm{mmol})$ in EGDA (3.47 g, $23.8 \mathrm{mmol}, 2$ equiv). The reaction mixture was incubated in an orbital shaker $\left(40{ }^{\circ} \mathrm{C}\right.$, $150 \mathrm{rpm}$ ) and the reaction progress was monitored by GC-FID. The enzyme was filtered off and the filtrate was extracted with $\mathrm{Et}_{2} \mathrm{O}(3 \times 15 \mathrm{~mL})$. The separated organic layer was dried over anhydrous $\mathrm{Na}_{2} \mathrm{SO}_{4}$, filtered, and evaporated in vacuo. An aliquot of the crude material was purified by FLC on silica gel (hexanes/AcOEt 1:1) to obtain an analytical sample of pure acetate $30 .{ }^{1} \mathrm{H} \mathrm{NMR}(300 \mathrm{MHz}$, $\left.\mathrm{CDCl}_{3}\right): \delta=4.12(\mathrm{t}, J=6.9 \mathrm{~Hz}, 1 \mathrm{H}, \mathrm{H}-1), 2.46(\mathrm{ddt}, J=6.9,4.4,2.6 \mathrm{~Hz}, 1 \mathrm{H}, \mathrm{H}-2), 2.07(\mathrm{~s}, 1 \mathrm{H}, \mathrm{Me}), 1.78(\mathrm{t}$, $J=2.6 \mathrm{~Hz}, 1 \mathrm{H}, \mathrm{H}-5)$.

General experiment for the competitive acetylations, according to Scheme 3. 
EGDA (1 equiv) and Lipozyme 435 (1\% wt) was added to an equimolar mixture of two alcohols $\left(0.5+0.5\right.$ equiv). The reaction mixture was stirred in an orbital shaker $\left(40^{\circ} \mathrm{C}, 150 \mathrm{rpm}\right)$ and the reaction progress was monitored by GC-FID. (see Table 2).

Chemo-selective acetylation of pentan-1-ol (39):

EGDA (16.6 g, $113.4 \mathrm{mmol})$ and Lipozyme $435(100 \mathrm{mg}, 1 \% \mathrm{wt})$ was added to an equimolar mixture of pentan-1-ol $39(5.0 \mathrm{~g}, 56.7 \mathrm{mmol})$ and pentan-3-ol $33(5.0 \mathrm{~g}, 56.7 \mathrm{mmol})$. The reaction mixture was stirred in an orbital shaker $\left(40^{\circ} \mathrm{C}, 150 \mathrm{rpm}\right)$ and the reaction progress was monitored by GC-FID. The enzyme was filtered off and the filtrate was hydro-distilled. The separated organic phase was diluted with hexane $(75 \mathrm{~mL})$, and washed with aq. $\mathrm{NaHCO}_{3}$ soln. $(3 \times 75 \mathrm{~mL}, \mathrm{pH} 9)$ and distilled water $(150 \mathrm{~mL})$. The separated organic phase was dried over $\mathrm{Na}_{2} \mathrm{SO}_{4}$ and concentrated in vacuo $\left(40{ }^{\circ} \mathrm{C}, 500\right.$ $\rightarrow 200$ mbar) to yield pent-1-yl acetate 40 as colourless oil (5.3 g, 94\% GC-FID purity, 68\% yield from 39). ${ }^{1} \mathrm{H}$ NMR $\left(300 \mathrm{MHz}, \mathrm{CDCl}_{3}\right): \delta=4.03(\mathrm{t}, J=6.8 \mathrm{~Hz}, 2 \mathrm{H}, \mathrm{H}-1), 2.02(\mathrm{~s}, 3 \mathrm{H}, \mathrm{Me}), 1.64-1.56(\mathrm{~m}, 2 \mathrm{H}$, $\mathrm{H}-2), 1.31(\mathrm{~m}, 4 \mathrm{H}, \mathrm{H}-3, \mathrm{H}-4), 0.90-0.87(\mathrm{~m}, 3 \mathrm{H}, \mathrm{H}-5) .{ }^{13} \mathrm{C} \mathrm{NMR}\left(75 \mathrm{MHz}, \mathrm{CDCl}_{3}\right): \delta=171.3(\mathrm{C}=\mathrm{O})$, 64.7 (C-1), 28.4 (C-2), 28.2 (C-3), 22.4 (C-4), 21.1 (Me), 14.0 (C-5). The obtained data fully correspond to the reported spectra [59].

\section{Conclusions}

In combination with Lipozyme 435, we have successfully employed EGDA as a useful acetylation reagent and solvent for chemo-selective and/or stereoselective enzymatic preparation of natural acetates for perfumery and/or flavour purposes. We found that such a green system exhibits high reactivity and selectivity toward activated (homo) allylic and non-activated primary/secondary alcohols. This feature was utilised in the scalable multigram synthesis of fragrant (Z)-hex-3-en-1-yl acetate $\mathbf{2}$ in $70 \%$ yield after vacuum rectification. In addition, the Lipozyme 435/EGDA system was also found to be applicable to the chemo-selective acetylation of (hydroxyalkyl) phenols as well as to the kinetic resolution of chiral secondary alcohols. Lastly, its remarkable discrimination power enabled the preferential acetylation of respective alcohol from the equimolar mixture of two isomeric substrates. Thus, pure 1-pentyl acetate 40 was isolated as a single product in $68 \%$ yield in a multigram quantity from the 1:1 mixture of 1-pentanol 39 and 3-pentanol 33.

Supplementary Materials: The following are available online: optimisation screening conditions, GC-FID retention times of all compounds, copies of chiral GC-FID and HPLC spectra, copies of NMR spectra of isolated compounds.

Author Contributions: Conceptualization and methodology, E.P. and P.S. Synthesis and analytics, E.P. Writing - original draft preparation, review and editing, E.P. and P.S. Supervision and project administration, P.S. Funding acquisition, P.S. All authors have read and agreed to the published version of the manuscript.

Funding: The Grant Agency of the Slovak Republic (VEGA 1/0162/20) funded this research.

Acknowledgments: We thank Veronika Výbohová and Katarína Hroboňová for chiral HPLC analyses. We very much appreciate the technical support from Axxence Slovakia Ltd.

Conflicts of Interest: The authors declare no conflict of interest.

\section{References}

1. Surburg, H.; Panten, J. Common Fragrance and Flavor Materials, 5th ed.; Wiley-VCH: Weinheim, Germany, 2006.

2. Anbu, N.; Nagarjun, N.; Jacob, M.; Kalaiarasi, J.M.V.K.; Dhakshinamoorthy, A. Acetylation of Alcohols, Amines, Phenols, Thiols under Catalyst and Solvent-Free Conditions. Chemistry 2019, 1, 69-79. [CrossRef]

3. Stergiou, P.-Y.; Foukis, A.; Filippou, M.; Koukouritaki, M.; Parapouli, M.; Theodorou, L.G.; Hatziloukas, E.; Afendra, A.; Pandey, A.; Papamichael, E.M.; et al. Advances in lipase-catalyzed esterification reactions. Biotechnol. Adv. 2013, 31, 1846-1859. [CrossRef] [PubMed]

4. Sá, A.G.A.; de Meneses, A.C.; de Araújo, P.H.H.; de Oliveira, D. A review on enzymatic synthesis of aromatic esters used as flavor ingredients for food, cosmetics and pharmaceuticals industries. Trends Food Sci. Technol. 2017, 69, 95-105. [CrossRef] 
5. Dhake, K.P.; Thakare, D.D.; Bhanage, B.M. Lipase: A potential biocatalyst for the synthesis of valuable flavour and fragrance ester compounds. Flavour Fragr. J. 2013, 28, 71-83. [CrossRef]

6. Gu, Y.; Jérôme, F. Glycerol as a sustainable solvent for green chemistry. Green Chem. 2010, 12, 1127-1138. [CrossRef]

7. Díaz-Álvarez, A.E.; Francos, J.; Lastra-Barreira, B.; Crocheta, P.; Cadierno, V. Glycerol and derived solvents: new sustainable reaction media for organic synthesis. Chem. Commun. 2011, 47, 6208-6227. [CrossRef]

8. García, J.I.; García-Marína, H.; Piresa, E. Glycerol based solvents: synthesis, properties and applications. Green Chem. 2014, 16, 1007-1033. [CrossRef]

9. Wolfson, A.; Atyya, A.; Dlugy, C.; Tavor, D. Glycerol triacetate as solvent and acyl donor in the production of isoamyl acetate with Candida antarctica lipase B. Bioprocess Biosyst. Eng. 2010, 33, 363-366. [CrossRef]

10. Milivojević, A.; Ćorović, M.; Carević, M.; Banjanac, K.; Vujisić, L.; Veličković, D.; Bezbradica, D. Highly efficient enzymatic acetylation of flavonoids: Development of solvent-free process and kinetic evaluation. Biochem. Eng. J. 2017, 128, 106-115. [CrossRef]

11. Varga, Z.; Kmecz, I.; Szécsényi, A.; Székely, E. Neat lipase-catalysed kinetic resolution of racemic 1-phenylethanol and a straightforward modelling of the reaction. Biocatal. Biotransformation 2017, 35, 427-433. [CrossRef]

12. Bayout, I.; Bouzemi, N.; Guo, N.; Mao, X.; Serra, S.; Riva, S.; Secundo, F. Natural flavor ester synthesis catalyzed by lipases. Flavour Fragr. J. 2020, 35, 209-218. [CrossRef]

13. Bourg-Garros, S.; Razafindramboa, N.; Pavia, A.A. Optimization of lipase-catalyzed synthesis of (z)-3-hexen-1-yl acetate by direct esterification in hexane and a solvent-free medium. Enzym. Microb. Technol. 1998, 22, 240-245. [CrossRef]

14. Bourg-Garros, S.; Razafindramboa, N.; Pavia, A.A. Large-scale preparation of (Z)-3-hexen-1-yl acetate using Candida antarctica-immobilized lipase in hexane. Biotechnol. Biochem. 1998, 59, 495-500.

15. Chiang, W.D.; Chang, S.W.; Shieh, C.J. Studies on the optimized lipase-catalyzed biosynthesis of cis-3-hexen-1-yl acetate in n-hexane. Process Biochem. 2003, 38, 1193-1199. [CrossRef]

16. Langrand, G.; Triantaphylides, C.; Baratti, J. Lipase catalyzed formation of flavour esters. Biotechnol. Lett. 1988, 10, 549-554. [CrossRef]

17. Chulalaknanukul, W.; Condoret, J.; Combes, D. Kinetics of geranyl acetate synthesis by lipase-catalysed transesterification in n-hexane. Enzyme Microb. Technol. 1992, 14, 293-298. [CrossRef]

18. Akoh, C.C.; Claon, P.A. Enzymatic synthesis of geranyl acetate in $n$-hexane with Candida antarctica lipases. J. Am. Chem. Soc. 1994, 71, 575-578.

19. Claon, P.A.; Akoh, C.C. Lipase-catalyzed synthesis of primary terpenyl acetates by transesterification: study of reaction parameters. J. Agric. Food Chem. 1994, 42, 2349-2352. [CrossRef]

20. Yee, L.N.; Akoh, C.C. Enzymatic synthesis of geranyl acetate by transesterification with acetic anhydride as acyl donor. J. Am. Oil Chem. Soc. 1996, 73, 1379-1384. [CrossRef]

21. Huang, S.; Chang, H. Kinetic study on the esterification of geraniol and acetic acid in organic solvents using surfactant-coated lipase. J. Chem. Technol. Biotechnol. 1999, 74, 183-187. [CrossRef]

22. Bartling, K.; Thompson, J.U.; Pfromm, P.H.; Czermak, P.; Rezac, M.E. Lipase-catalyzed synthesis of geranyl acetate in $n$-hexane with membrane-mediated water removal. Biotechnol. Bioeng. 2001, 75, 676-681. [CrossRef] [PubMed]

23. Peres, C.; Harper, N.; da Silva, M.D.R.G.; Barreiros, S. Effect of zeolites on lipase catalyzed esterification in nonaqueous media. Enzyme Microb. Technol. 2005, 37, 145-149. [CrossRef]

24. Barahona, D.; Pfromm, P.H.; Rezac, M.E. Effect of water activity on the lipase catalyzed esterification of geraniol in ionic liquid [bmim] $\mathrm{PF}_{6}$. Biotechnol. Bioeng. 2006, 93, 318-324. [CrossRef] [PubMed]

25. De la Casa, R.M.; Sinisterra, J.V.; Sánchez-Montero, J.M. Characterization and catalytic properties of a new crude lipase from C. Rugosa. Enzyme Microb. Technol. 2006, 38, 599-609. [CrossRef]

26. Antoniotti, S.; Fernandez, X.; Duñach, E. Reaction design for evaluation of the substrate range of hydrolases. Biocatal. Biotransformation 2008, 26, 228-234. [CrossRef]

27. Couto, R.; Vidinha, P.; Peres, C.; Ribeiro, A.S.; Ferreira, O.; Oliveira, M.V.; Macedo, E.A.; Loureiro, J.M.; Barreiros, S. Geranyl Acetate Synthesis in a Packed-Bed Reactor Catalyzed by Novozym in Supercritical Carbon Dioxide and in Supercritical Ethane. Ind. Eng. Chem. Res. 2011, 50, 1938-1946. [CrossRef]

28. Lozano, P.; Bernal, J.M.; Navarro, A. A clean enzymatic process for producing flavour esters by direct esterification in switchable ionic liquid/solid phases. Green Chem. 2012, 14, 3026-3033. [CrossRef] 
29. Gupta, A.; Dhakate, S.R.; Pahwa, M.; Sinha, S.; Chand, S.; Mathur, R.B. Geranyl acetate synthesis catalyzed by Thermomyces lanuginosus lipase immobilized on electrospun polyacrylonitrile nanofiber membrane. Process Biochem. 2013, 48, 124-132. [CrossRef]

30. Badgujar, K.C.; Bhanage, B.M. Synthesis of geranyl acetate in non-aqueous media using immobilized Pseudomonas cepacia lipase on biodegradable polymer film: Kinetic modelling and chain length effect study. Process Biochem. 2014, 49, 1304-1313. [CrossRef]

31. Lozano, P.; Bernal, J.M.; Gómez, C.; García-Verdugo, E.; Burguete, M.I.; Sánchez, G.; Vaultier, M.; Luis, S.V. Green bioprocesses in sponge-like ionic liquids. Catal. Today 2015, 255, 54-59. [CrossRef]

32. Adarme, C.A.A.; Leão, R.A.C.; de Souza, S.P.; Itabaiana, I., Jr.; de Souza, R.O.M.A.; Rezende, C.M. Continuous-Flow Chemo and Enzymatic Synthesis of Monoterpenic Esters with Integrated Purification. Mol. Catal. 2018, 453, 39-46. [CrossRef]

33. Murcia, M.D.; Gómez, M.; Gómez, E.; Gómez, J.L.; Hidalgo, A.M.; Sánchez, A.; Vergara, P. Kinetic modelling and kinetic parameters calculation in the lipase-catalysed synthesis of geranyl acetate. Chem. Eng. Res. Des. 2018, 138, 135-143. [CrossRef]

34. Perdomo, I.C.; Gianolio, S.; Pinto, A.; Romano, D.; Contente, M.L.; Paradisi, F.; Molinari, F. Efficient Enzymatic Preparation of Flavor Esters in Water. J. Agric. Food Chem. 2019, 67, 6517-6522. [CrossRef] [PubMed]

35. Yadav, G.D.; Devendran, S. Lipase catalyzed synthesis of cinnamyl acetate via transesterification in non-aqueous medium. Process Biochem. 2012, 47, 496-502. [CrossRef]

36. Wolfson, A.; Dlugy, C.; Karanet, A.; Tavor, D. A sustainable one-pot synthesis of cinnamyl acetate in triacetin. Tetrahedron Lett. 2012, 53, 4565-4567. [CrossRef]

37. Geng, B.; Wang, M.; Qi, W.; Su, R.; He, Y. Cinnamyl acetate synthesis by lipase-catalyzed transesterification in a solvent-free system. Biotech. Appl. Biochem. 2012, 59, 270-275. [CrossRef] [PubMed]

38. Wu, Z.; Qi, W.; Wang, M.; Su, R.; He, Z. Lipase immobilized on novel ceramic supporter with Ni activation for efficient cinnamyl acetate synthesis. J. Mol. Catal. B Enzym. 2014, 110, 32-38. [CrossRef]

39. Tomke, D.P.; Rathod, V.K. Ultrasound assisted lipase catalyzed synthesis of cinnamyl acetate via transesterification reaction in a solvent free medium. Ultrason. Sonochemistry 2015, 27, 241-246. [CrossRef]

40. Badgujar, K.C.; Sasaki, T.; Bhanage, B.M. Synthesis of lipase nano-bio-conjugates as an efficient biocatalyst: characterization and activity-stability studies with potential biocatalytic applications. RSC Adv. 2015, 5, 55238-55251. [CrossRef]

41. Perdomo, I.C.; Contente, M.L.; Pinto, A.; Romano, D.; Fernandes, P.; Molinari, F. Continuous preparation of flavour-active acetate esters by direct biocatalytic esterification. Flavour Fragr. J. 2020, 35, 190-196. [CrossRef]

42. Nishio, T.; Takahashi, K.; Yoshimoto, T.; Kodera, Y.; Saito, Y.; Inada, Y. Terpene alcohol ester synthesis by polyethylene glycol-modified lipase in benzene. Biotechnol. Lett. 1987, 9, 187-190. [CrossRef]

43. Yanagishita, H.; Sakaki, K.; Hirata, H. Optical Resolution of 2-Alkanol by Lipase-Catalyzed Acetylation with Vinyl Acetate in Packed-Bed Reactor with Recycling System. J. Oleo Sci. 2007, 56, 137-148. [CrossRef] [PubMed]

44. Dlugy, C.; Wolfson, A. Lipase catalyse glycerolysis for kinetic resolution of racemates. Bioprocess Biosyst. Eng. 2007, 30, 327-330. [CrossRef]

45. Zarcula, C.; Corîci, L.; Croitoru, R.; Ursoiu, A.; Peter, F. Preparation and properties of xerogels obtained by ionic liquid incorporation during the immobilization of lipase by the sol-gel method. J. Mol. Catal. B. Enzym. 2010, 65, 79-86. [CrossRef]

46. Strohalm, H.; Dold, S.; Pendzialek, K.; Weiher, M.; Engel, K.H. Preparation of Passion Fruit-Typical 2-Alkyl Ester Enantiomers via Lipase-Catalyzed Kinetic Resolution. J. Agric. Food Chem. 2010, 58, 6328-6333. [CrossRef] [PubMed]

47. Tomin, A.; Weiser, D.; Hellner, G.; Bata, Z.; Corici, L.; Péter, F.; Koczka, B.; Poppe, L. Fine-tuning the second generation sol-gel lipase immobilization with ternary alkoxysilane precursor systems. Process Biochem. 2011, 46, 52-58. [CrossRef]

48. Hellner, G.; Boros, Z.; Tomin, A.; Poppe, L. Novel Sol-Gel Lipases by Designed Bioimprinting for Continuous-Flow Kinetic Resolutions. Adv. Synth. Catal. 2011, 353, 2481-2491. [CrossRef]

49. Schober, M.; Gadler, P.; Knaus, T.; Kayer, H.; Birner-Grünberger, R.; Gülly, C.; Macheroux, P.; Wagner, U.; Faber, K. A Stereoselective Inverting sec-Alkylsulfatase for the Deracemization of sec-Alcohols. Org. Lett. 2011, 13, 4296-4299. [CrossRef] 
50. Kazlauskas, R.J.; Weissfloch, A.N.E.; Rappaport, A.T.; Cuccia, L.A. A rule to predict which enantiomer of a secondary alcohol reacts faster in reactions catalyzed by cholesterol esterase, lipase from Pseudomonas cepacia, and lipase from Candida rugosa. J. Org. Chem. 1991, 56, 2656-2665. [CrossRef]

51. Yuasa, Y.; Shibuya, S.; Yuasa, Y. Resolution of Racemic Rhododendrol by Lipase-Catalyzed Enantioselective Acetylation. Synth. Commun. 2003, 33, 1469-1475. [CrossRef]

52. Kitayama, T.; Isomori, S.; Nakamura, K. Asymmetric synthesis of enantiomerically pure zingerols by lipase-catalyzed transesterification and efficient synthesis of their analogues. Tetrahedrom Asymmetry 2013, 24, 621-627. [CrossRef]

53. Karume, I.; Takahashi, M.; Hamdan, S.M.; Musa, M.M. Deracemization of Secondary Alcohols by using a Single Alcohol Dehydrogenase. ChemCatChem 2016, 8, 1459-1463. [CrossRef]

54. Velusamy, S.; Borpuzari, S.; Punniyamurthy, T. Cobalt (II)-catalyzed direct acetylation of alcohols with acetic acid. Tetrahedron 2005, 61, 2011-2015. [CrossRef]

55. Miyazawa, T.; Yamamoto, M.; Danjo, H. Chemoselective acylation of (hydroxyalkyl) phenols catalyzed by Candida antarctica lipase B. Biotechnol. Lett. 2013, 35, 625-630. [CrossRef]

56. Song, L.; Liu, Y.; Tong, R. Cephalosporolide B Serving as a Versatile Synthetic Precursor: Asymmetric Biomimetic Total Syntheses of Cephalosporolides C, E, F, G, and (4-OMe-)G. Org. Lett. 2013, 15, 5850-5853. [CrossRef]

57. Kulangiappar, K.; Anbukulandainathan, M.; Raju, T. Nuclear Versus Side-Chain Bromination of 4-Methoxy Toluene by an Electrochemical Method. Synth. Commun. 2014, 44, 2494-2502. [CrossRef]

58. Boffi, A.; Cacchi, S.; Ceci, P.; Cirilli, R.; Fabrizi, G.; Prastaro, A.; Niembro, S.; Shafir, A.; Vallribera, A. The Heck Reaction of Allylic Alcohols Catalyzed by Palladium Nanoparticles in Water: Chemoenzymatic Synthesis of (R)-(-)-Rhododendrol. ChemCatChem 2011, 3, 347-353. [CrossRef]

59. Kumar, H.M.; Joyasawal, S.; Reddy, B.V.S.; Chakravarthy, P.P.; Krishna, A.D.; Yadav, J.S. Reaction of orthoesters with alcohols in the presence of acidic catalysts: a study. Indian J. Chem. 2005, 44, 1686-1692. [CrossRef]

Sample Availability: Samples of the compounds are not available from the authors.

(C) 2020 by the authors. Licensee MDPI, Basel, Switzerland. This article is an open access article distributed under the terms and conditions of the Creative Commons Attribution (CC BY) license (http://creativecommons.org/licenses/by/4.0/). 